Yayınlayan: Ankara Üniversitesi KASAUM

Adres: Kadın Sorunları Araştırma ve Uygulama Merkezi, Cebeci 06590 Ankara

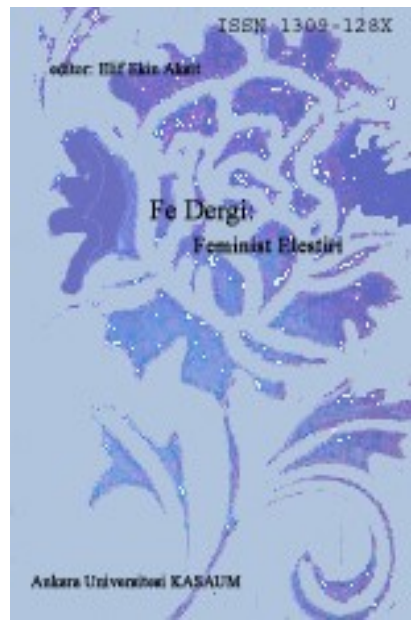

Fe Dergi: Feminist Eleştiri 12, Sayı 2

Erişim bilgileri, makale sunumu ve ayrıntılar için:

http://cins.ankara.edu.tr/

Türkiye futbolunda kadın: "İ̧"i olmayan ve olmamast gereken yerde

Yağmur Nuhrat

Çevrimiçi yayına başlama tarihi: 20 Aralık 2020

Yazı Gönderim Tarihi: 30.03 .2020

Yazı Kabul Tarihi: 25.09.2020

Bu makaleyi alıntılamak için: Yağmur Nuhrat, "Türkiye Futbolunda Kadın: "İş̧i Olmayan ve Olmaması Gereken Yerde" Fe Dergi 12, no. 2 (2020), 45-58. URL: http://cins.ankara.edu.tr/24_4.pdf

$\mathrm{Bu}$ eser akademik faaliyetlerde ve referans verilerek kullanılabilir. Hiçbir şekilde izin alınmaksızın çoğaltılamaz. 
Türkiye Futbolunda Kadın: “iş”i Olmayan ve Olmaması Gereken Yerde Yağmur Nuhrat

Futbol dünyanın birçok yerinde esas olarak bir erkek meşgalesi. Dahası, baskın erkekliğin kurulmasında önemli rol oynuyor. Bu da beraberinde kadın futbolunun ikincilleştirilmesini, değersiz ve önemsiz görülmesini ve futbol üzerinden kadının ötekileştirilmesini getiriyor. Bu yazıda, değersizleştirmenin bileşenleri olarak futbolun kadın için bir iş olmaktansa hobi ya da bir toplumsal ilerleme aracı olarak değerlendirildiğini öne sürüyorum ve buradan hareketle de futboldaki kadının "olmamast gereken yerde olan" ve tehdit ("matter out of place") muamelesi gördügü savinı ortaya koyuyorum. Böylece sadece kavramsal ya da sembolik olarak değil, fiziksel ve duyusal olarak da kadınin futbolun dışına itilmesini ayrintılandirlyorum. Yazı, 2019 ve 2020 senelerinde toplamda dört ay çoğunlukla İstanbul'da yaptı̆̆ım niteliksel saha çalı̧̧mama dayanıyor. Çalışma süresince futbolcu, antrenör, kulüp ve federasyon yetkilileri, spor gazetecileri ve sponsorlarla derinlemesine görüsmeler ve maçlarda gözlem yaptım

Anahtar Kelimeler: Kadın futbolu, ötekileştirme, araçsallaştırma, hobileştirme, "olmaması gereken yerde olma"

\begin{abstract}
Women in football in Turkey: Nonworkers out of place
Football (soccer) around the world is predominantly a masculine engagement. Moreover, it is a key practice in the production and reinforcement of hegemonic masculinity. As such women's football is largely overlooked and trivialized and women are othered through football. In this paper, I demonstrate how such trivialization entails an outlook whereby football is deemed a hobby or a social instrument for women rather than work. Feeding off of this viewpoint, women in football are perceived and treated as threatening "matter out of place." Through this, I show that women are pushed out of football not only conceptually and symbolically but also quite physically. This paper is based on four months of qualitative research in 2019 and 2020, mostly in Istanbul when I interviewed footballers, trainers, club and federation administrators, media representatives and sponsors and conducted observation at matches.
\end{abstract}

Keywords: Women's football, othering, instrumentalization, hobby versus work, "matter out of place"

\title{
Giriş
}

Bir Beşiktaş maçı günüydü. Köyiçi kalabalık, Dolmabahçe yangın yeri, stadyum çevresi korumalıydı. Yine futbol, yine siyah-beyaz, yine 40 bin kişilik Vodafone Park Stadyumu, yine bir hafta sonu... Bunlarla beraber, o günü olağan hafta sonlarından ayıran iki fark vardı. Tarih 7 Mart 2020'ydi; Beşiktaş tarafını temsil eden burada ilk defa maç yapacak kadın futbol takımıydı. Taraftar ise Passolig'siz, e-biletsiz ve bedelsiz kağıt biletleriyle stada gelmiş̧ti; bağırıyor, çağırıyor, şarkılar söylüyordu. Günün sloganını sponsor Vodafone, "ben varım" olarak belirlemiş, stadyum anonsları on binleri aynı anda "ben varım" diye haykırtıyordu.

$\mathrm{Bu}$ yazı kadının futbolda var olması, yer edinmesi, yer edinirken nasıl konumlandırıldığıyla ilgili. Futbol, dünyanın hemen her yerinde bir erkek pratiği (Meân 2001, Pfister 2015a, Scraton vd. 1999). Baskın erkekliğin motiflerini yeniden üretiyor ve erkek sosyalleşmesinin, erkekliğin tahsis edilmesinin önemli bir öğesi (bkz. Connell 1987). Bunun böyle olmadığı yerlerde, örneğin ABD'de bile, kadın ve erkek profesyonel futbolcular eşit ücret almıyor; kadının futbol pratiğine erkeğinki kadar değer biçilmiyor (Guardian 2019, ayrıca bkz. Coche 2016, Allison 2018). Çünkü, uluslararası ve Türkiye üzerinden futbol tahlili yapan araştırmacıların ortaya koyduğu gibi, kadın futbolun "ötekisi” (Magee vd. 2007, Öztürk ve Koca 2018) ve buradan hareketle çeşitli bağlam ve kesişen eksenlerde bir mücadele alanı (Fozooni 2008, Harkness 2012, Clark 2011, Themen

\footnotetext{
*Dr. Öğretim Üyesi, İstanbul Bilgi Üniversitesi, Sosyoloji Bölümü, https://orcid.org/0000-0002-3663-9274, yagmur.nuhrat@bilgi.edu.tr, Yaz1 Gönderim Tarihi: 30.03.2020, Yaz1 Kabul Tarihi: 25.09.2020
} 
2016). Bu yazıda bu "ötekileştirme"yi ayrıntılandırmayı hedefliyorum. Bunu yapmak için önce kadının futbol oynama pratiğinin bir "iş” olarak algılanmadığını, hobileştirildiğini ve araçsallaştırıldığını anlatacağım. Buna bağlı olarak da futbol oynayan kadının "olmaması gereken” ya da "yanlış" yerde olan (bkz. Douglas 1966) muamelesi gördüğünü, yani bir tehdit unsuru olarak algılandığını, ortaya koyacağım. Başka bir deyişle, bu yazının hedefi kadın futbolu konusunda sıkça dile getirilen ötekileştirme kavramını çözümlemek ve antropolojik bir "yerinde olma/olmama" kavramsallaştırmasına işaret etmek.

$\mathrm{Bu}$ yaklaşım ötekileştirme literatürünü zenginleştiriyor çünkü kadının futboldan itilmesinin sadece sembolik ya da kavramsal olarak değil, fiziksel ve duyusal da olabildiğini vurguluyor. Mary Douglas (1966) Saflık ve Tehlike kitabında kiri, pisi, çöpü "olmaması gereken yerde olan” (matter out of place) biçiminde tanımlar. Yani "kir" aslında bir karışmanın, katışmanın, bir ihlalin, sınır aşımının sonucunda karşımıza çıkandır. Yerinde olmanın, düzenin sunduğu temizlik algısının verdiği güveni tehdit eder ve normu temelden zorlar, tehdit eder. Futbolcu kadının futboluna iş, meslek ya da kariyer olarak bakmaktansa bunu bir hobi ya da bir araç olarak değerlendirmek kadının futbolda ötekileştirilmesinin bir sonucu ve bunu destekliyor. Futbolcu kadını bu alana ait olarak düşünmeyi engelleyen bu yaklaşım onun "olmaması gereken yerde" olduğu algısını da besliyor.

$\mathrm{Bu}$ makale Türkiye'de kadın futboluyla ilgili tarihsel bilgiyle başlıyor. Ardından kadın liglerinin bugünkü yapılanmasını anlatıyor ve özellikle birinci ligdeki takımlarla ilgili bilgi veriyor. Bir sonraki bölümde kadın emeğinin "iş”tten sayılmadığı başka alanların sunduğu içgörüden beslenerek, kadının futbol pratiğinin "iş" olarak değerlenmemesini çözümlüyorum; hobileştirme ve araçsallaştırma dinamiklerine 1şı tutuyorum. Sonrasında ise bu dinamiklerden hareketle makalenin temel savını kuruyorum ve kadının Türkiye'de futboldan fiziksel ve duyusal olarak dışlanmasını ayrıntılandırıyorum.

\section{Araştırma süreci}

Bu yazı Kasım 2019 ve Şubat 2020 arasında çoğunlukla İstanbul'da yürüttüğüm niteliksel araştırmaya dayanıyor. Bu süre içinde Türkiye liglerinde futbol oynamakta olan ve yaşları on sekiz ve otuz dört arasında değişen on kadınla yüz yüze derinlemesine görüşme yaptım. Bu on futbolcunun yanı sıra bir takımın yedi oyuncusu ve antrenörüyle bir grup mülakatı yapma firsatı buldum. ${ }^{1}$ Ek olarak, 2000'lerde ve 1990'larda futbol oynamış (biri Türkiyeli olmayan) iki eski futbolcuyla telefonda görüştüm; böylece ilgilendiğim konulara ilişkin daha geniş bir bakış açısı edinme imkanı buldum. ${ }^{2}$

Futbolcu görüşmelerine devam ederken, bu evrene ilişkin fikir edinmek için antrenör, medya, yönetici (kulüp ve federasyon) ve sponsor gibi başka aktörlerle de konuşmam gerektiğini anladım. Dolayısıyla katılımcı belirlerken benim için önemli olan kişinin kadın futbol evreninde fail olmasıydı. Üç ayrı (ikisi erkek) antrenörle yüz yüze ve bir başka kadın antrenörle telefonda görüşme yaptım. Eurosport, beIN ve TRT'de çalışan toplam dört spor gazetecisi (hepsi kadın), kadın futbolunun önde gelen sponsorlarından Avon'un bir kadın temsilcisi, İstanbul'da bir kulüp yönetiminden iki kişi (biri erkek) ve Türkiye Futbol Federasyonu'ndan (TFF) kadın futboluyla ilgili iki erkek yöneticiyle yüz yüze görüşmeler yaptım.

İlk görüştügüm dört futbolcu katılımcıya, üç antrenöre, TFF'deki ve Eurosport'taki katılımcılara, ve görüştüğüm eski futbolculardan birine bireysel ve profesyonel iletişim ağlarım sayesinde ulaştım. Ardından kartopu yöntemini kullanarak diğer katılımcılara eriştim. ${ }^{3}$ Araştırmanın başında ele aldığım kavram "eşitlik," ve farklı aktörlerin bu kavramı nasıl anlamlandırdıkları sorusuydu. Elde ettiğim verinin bir kısmı ise bana bu yazının konusu olan yerinde olma/olmama algısına ilişkin çözümleme fırsatı sundu. Derinlemesine görüşmelerin yanında İstanbul'un birinci ligdeki dört takımının iç saha maçlarında gözlemler yaptım; İzmir'de bir antrenman izleyebildim. Son olarak, bu araştırma kadın futbolu üzerine çalışan akademisyenlerle yaptığım fikir alışverişlerinden faydaland. Onlarla birlikte, toplamda otuz sekiz kişi araştırmama dahil oldu ve otuz biri kadındı.

Görüşmelerde ayrıntılı yazılı notlar aldım fakat ses kaydı almadım. Katılımcılar (ki bazılarının takımlarını, kurumsal hiyerarşideki yerlerini, ya da unvanlarını dahi yukarıdaki paragraflarda bilerek muğlak yazdım) birçok konudan söz ederken tedirgin, ürkek ve çekingendi. Kadın futbolu hikayeleri çoğu zaman yok sayılma, değersiz görülme, desteklenmeme hikayeleri. Aynı zamanda emek sömürüsü ve homofobi hikayeleri. Bu konularla ilgili zaten tutuk olan birçok katılımcı için ses kaydı seçeneği tamamen suskunlaştırıcı olacaktı. Bu nedenle, bu yazıda sunduğum alıntılar kelimesi kelimesine değildir. Ancak, her görüşmenin hemen sonrasında notlarımı daha da ayrıntılandırarak temize çektim ve analitik olarak önemli gördüğüm ifadeleri burada ağızdan çıktığı biçimde aktarmaya son derece dikkat gösterdim. 


\section{Türkiye'de kadın futbolu}

Ülkede kadın ve futbolun birlikte anıldığı, kadın futboluna ilişkin ilk kamusal alan konuşması kadının futbol oynayıp oynayamayacağı üzerine ve 1929'da Akşam gazetesinde kayıt ediliyor. Kaydı olan ilk kadın futbolu maçı ise İstanbul ve İzmir'den iki takım arasında 1954'te İstanbul'da oynanıyor ama bazı kaynaklara göre İzmir takımı bu maça çıkmadığı için İstanbul takımı ancak kendi içinde ikiye ayrılarak maç yapabiliyor (Toklucu 2016). Mart 1968 'te bir kadın takımı kurmak için başvuru yapılıyor ve oynayacak oyuncuların eşlerinden, bekarlarsa da babalarından yazılı izin getirmeleri şart koşuluyor (Cumhuriyet 1968). "Hanım futbolcuların" bu başvurusunun sonunda ise kurulan bir takım olmuyor (Ataşehir Ekspres 2016).

Ardından, 1970’lerin başında ilk kadın takımı Kınalıada Spor Kulübü içinde bir "kız” takımı olarak kuruluyor; sonrasında ismi Dostlukspor olarak değişiyor. Bu takımın oyuncularının maç yapacak başka kadın takımı bulamadıklarından şikayet ettiklerinin kayıtları var (Öztürk ve Koca 2015). Özellikle mahalle aralarındaki halı sahaların sayısının artmasıyla birlikte, 1980'lerde, kadın takımı sayısı artıyor (Toklucu 2016). Futbolcuların lig kurma talepleri artıyor; 1985 'te TFF'nin bu konuda bir girişimi oluyor ama futbol kalitesi yetersiz görüldüğü için proje erteleniyor (Orta 2014).

Örgütlü bir kadın liginin kurulması bir on yıl daha alıyor. Mart 1994'te on altı takımlı "Bayanlar Futbol Ligi” kuruluyor (kadın sporunda "bayan” kelimesi kullanımıyla ilgili bkz. Arpinar-Avsar, Girgin ve Bulgu 2014). En başarılı takım dört sene üst üste şampiyonluk alan ve bir halı firmasına ait olan Dinarsu takımı. Dinarsu ulusal başarısının yanı sıra Avrupa'da turnuvalara da katılıyor fakat 1997'de destek eksikliğinden ötürü ligden çekiliyor (Özgen 2014). Bu nedenlerden ötürü bir takımın kapatılması ya da ligden çekilmesi 1990’larda sık görülen, bugün de devam eden bir örüntü (Öztürk ve Koca 2015).

Kadın milli takımı 1995'te bir araya geliyor ve lig de 2003 yılına kadar devam ediyor. Sonrasında, 2003 ve 2006 yılları arasında, kadın ligine ara veriliyor. ${ }^{4}$ Lig 2006'da yeniden başlıyor ve bugün üç ayrı lig halinde devam ediyor. Birinci ligde 12, ikinci ligde 13 ve üçüncü ligde de her birinde altı ila 11 takım olan dokuz grup var. Yıldız ve minik takımlarla birlikte, TFF'den bireysel olarak alabildiğim kayıtlara göre, 2019 sonu itibarıyla Türkiye'de 3500 üzerinde lisanslı kadın futbolcu var. ${ }^{5}$ Bununla beraber, 2020 itibarıyla hala TFF'de bir kadın futbolu departmanı yok. Kadın futbolu Futbol Gelişim Direktörlüğü ve milli takım çatısı altında yönetiliyor ve biçimleniyor.

Birinci ligdeki 12 takım arasından dördü İstanbul'da, biri hemen çeperinde Kocaeli'nde, bir diğeri de yine yakında Zonguldak'ta. Ankara, İzmir ve Adana'nın birer takımı var. Güneydoğu'dan ise Diyarbakır, Hakkari ve Gaziantep'in takımları var. İstanbul'un üç takımı (Kireçburnu, Fatih Vatan ve Ataşehir), Ankara takımı FOMGET, İzmir takımı Konak, Zonguldak takımı Karadeniz Ereğli ve Hakkari takımı Hakkarigücü birer belediye takımı. Ülkede üst düzey başarı elde etmiş kulüplerden sadece Beşiktaş’ın bir kadın takımı var. Gaziantep'in ALG Spor takımı ALG tekstil firmasının bir girişimi. Diyarbakır'ın Amed Sportif Faaliyetler takımı 1990'da, başka bir isimle, belediye takımı olarak kurulmuş olmasına rağmen, çeşitli siyasi süreçler sonunda 2017'den itibaren belediye desteği olmadan futbol oynamakta. ${ }^{6}$ Adana (İdman Yurdu) ve Kocaeli (Bayan) takımları bireysel girişimler sayesinde kurulmuş takımlar. Beşiktaş dışında tüm bu kulüplerin ya sadece kadın futbol branşı var ya da kadın futbolu kulübün önde giden, erkek futbolundan daha üst bir ligde icra edilen, kolu. Ligin yeniden başladığı 2006'dan sonra Ataşehir (üç şampiyonluk) ve Konak (beş şampiyonluk) en başarılı takımlar oldu. Birinci lige çıkışının üç sezon sonrasında, 2019 yılında, Beşiktaş, ALG’yle haftalar boyunca kafa kafaya oynadıktan sonra, şampiyon oldu; ALG ise kovaladığı şampiyonluğu 2020 sezonunun sonunda elde etti.

\section{Kadına "hobi" ya da "araç" olarak futbol}

Bu makalenin yazım döneminde yayımlanan bir yazı dizisi ve ilham verdiği başka yazılar Türkiye’de kadın liglerinin toplumsal, siyasi ve ekonomik dinamikler çerçevesinde ikincilleştirildiğini ve yok sayıldığını anlatıyor (Göktürk 2020, Talimciler 2020). Ben de araştırmam sırasında, dünyanın başka yerlerinde olduğu gibi (da Costa 2014, Cox ve Pringle 2011, Pfister 2015b, Ravel ve Gareau 2016) Türkiye'de de kadın futbolunun, bu ikincilleştirmenin bir boyutu olarak, değersizleştirildiğini ve önemsizleştirildiğini gördüm. Bu makalede bu konuyu doğrudan ele almıyorum. Ama bu bölümde, önemsizleştirmenin bir bileşeni olan, futbolu kadın için "iş," "meslek" ya da "kariyer"den saymama durumuna eğiliyorum çünkü bir sonraki bölümde ayrıntılandıracağım merkez meselem yani futboldaki kadının "yerinde olmama" hali, futbolun kadın için bir "iş" olarak düşünülmemesinden besleniyor. 
Neyin "iş"ten sayıldığı kadın emeği konusunda sık dile getirilmiş bir konu. Özellikle ev içi ve bakım işleri dünyanın genelinde kadınlara yükleniyor (Glazer 1984, Kotiswaran 2011, Bora 2015, Erdoğdu ve Toksöz 2013). Bu işleri ve beraberinde gelen duygusal emeği (Hochschild 1983, Zimmerman 2015) omuzlayan kadınlar, kadınlıklarının bir uzantısı olarak icra ettikleri varsayılan (Ortner 1974, Federici 1975), tanım ve kapsamları çoğu zaman muğlak olan bu işlerin karşılığında ya ücret almıyorlar ya da düşük ücretler alıyorlar. Dolayısıyla "iş"i “iş” olarak tanımlamak, emeği görünür kılmak ve hakkını vermek açısından önemli. Benim araştırma göre, futbolda da kadın emeği "iş”ten sayılmıyor; (kadın futbolcular tarafından dahi) bir "hobi” olduğu düşünülüyor. Ayrıca, futbolun kadın için içkin bir değere sahip olduğu değil ancak bir araç olduğu algısı yaygın. Yani, yukarıdaki bağlamdan farklı olarak, sayılmama hali kadının zaten orada olması gerektiği değil, orada olmaması gerektiği varsayımıyla örülü.

Aşağıdaki alıntılar, futbolun kadın için bir "hobi" olduğu değerlendirmesinin gömülü olduğu ağın bileşenlerini sunuyor. Kadın futbolcular hayatlarını idame ettirecek kadar para kazanmıyorlar. Sözleşmesiz ya da bağlayıcılığg olmayan birer senelik sözleşmelerle oynadıkları için ücretlerin aksadığı durumlarda hak talep edecek araçlardan yoksunlar. ${ }^{7} \mathrm{Bu}$ maddi yoksunluk (yine aşağıda anlatacağım araçsallaştırmayla birlikte) beraberinde üniversite eğitimini ve başka meslekler edinmeyi getiriyor. Normatif olarak zaten kadınla özdeşleşmeyen futbol bu dinamikler sayesinde kadınların kendisi tarafından bile bir kadın kariyeri olarak tahayyül edilemiyor. Görüştüğüm futbolculardan Nergis şöyle anlatıyor: ${ }^{8}$

Bizim şu ana kadar beş maç oldu...Dört-beş tane kovulan futbolcu oldu. Yani kontrat var ama yok. Bir sene sözleşmen var diye hiçbir şey olmuyor. Çok çok zor, bunun peşinden gitmek istesen. Bana "gelme, oynama” deseler, ben hiçbir şey yapamam. Transfer sezonu Ocak. Beklemem lazım. İdman yapacaksın, kendini hazır tutman lazım. "Maddiyattan kısmak" derler, kovarlar.

Bu sözlerin ardından, 10 senedir futbol oynayan ve yurt dışı deneyimi de olan Nergis'e, futbolu bir kariyer olarak görüp görmediğini soruyorum:

Yok görmüyoruz zaten. Benim ailem diyor "kariyerini çok aksatıyorsun. Hobi olarak yap. Çok erteliyorsun kariyerini.” Ailem de bunu söylüyor, arkadaşlarım da bunu söylüyor.

“Meslek” ve "hobi” ikiliği üniversite eğitimi kapsamında dillenebiliyor. Delal'e göre:

Türkiye'de bu bir kariyer değil. Millilerin bile mesleği beden eğitimi öğretmenliği. Bunu sırf sevdiği için yapıyor. Hobi olarak yaparım. Zaten BESYO [Beden eğitimi ve spor yüksekokulu] okuyorum. İleride mesleğim olur. Hobi olarak ancak. Maddi olarak çünkü geçim sağlayamazsın. Meslek ve futbol ikisi de olması lazım. Mesleğin olursa, neden futbol da oynamayasın ki? Ama maddi tatmin olsa, yüzde 90 okul okumazdı. Belki yanlış ama öyle. Bir çok insan maddi imkansızlıklardan dolayı okul okuyor.

$\mathrm{Bu}$ anlatının başka futbolcular nezdinde nasıl değerlendirdiğini anlamak için hali hazırda yüksek lisans başvurusu planlayan Nil'e futboldan yeterli maaşı alsa yüksek lisans düşünüp düşünmeyeceğini sordum:

Yok ya ne yüksek lisansı. Üniversite de...hani okurdum ama bitirmezdim. "Cepte bir mesleğin olsun" diye düşünmezdim... Yani kadın futbolu Türkiye’de hobi gibi. Meslek olarak yapamazsın.

Her ne kadar bu durum kabullenilmiş gibi görünse de, bir "sporcu hayatı"na ya da futbolu "iş” olarak yapabilmeye öykünmeler olduğunu gördüm. İstanbul'da bir plazada fitness uzmanı olarak çalışan Merve şöyle anlattı:

Ben de isterdim sporcu hayatı yaşamak. Sabah idmanımı yapayım. Sonra eve

Geleyim ayaklarımı uzatayım sonra akşam yine idmana gideyim. Ama bir böyle bir hayat yaşayamıyoruz. Biz sadece futboldan aldığımız parayla hayatımızı kazanamıyoruz.

Benzer biçimde Büke “"Türkiye'de bu işi iş olarak yapmayı hedefliyorum' diyebilmek çok isterdim” diye vurguladi. 
Kenda Stewart (2012) "hobi" ve "meslek" ikiliğini Filistinli kadınların futbol pratikleri çerçevesinde tartışıyor ve her ne kadar futbolu kadına "hobi" olarak yakıştırmanın toplumsal ve cinsiyetlendirilmiş işbölümlerini desteklediğini ortaya koysa da, kadınların (hobi olarak dahi de olsun) futbol oynayarak tutku ve hayallerini gerçekleştirebildiğini ve tam da hobi olarak ifade edildiği için bu alana erișebildiklerini yazıyor. Benim gördüğüm ise, "hobi” tayini özellikle de aşağıda anlattığım araçsallaştırmayla birleştiğinde futboldaki kadını "olması gereken yerde olmayan” biçiminde tanımlaya hizmet ediyor.

Futbol kadınlar için bir hobi olarak görülmenin yanı sıra onları "kurtaracak" bir araç olarak görülüyor. $\mathrm{Bu}$ özellikle futboldaki hakimiyetini kadın futbolunun karar verici pozisyonlarında devam ettiren erkeklerin ifadelerinde mevcut (ayrica bkz. Stirling ve Schulz 2011, Karaçam ve Koca 2019). Görüştügüum antrenörlerden biri, Hakan, şöyle anlattı:

Bizim amacımız futbolcu yetiştirmek değil. Futbolcuyu yetiştireceğiz de ne olacak? Amacımız güçlü kadınlar yetiştirmek. Biz bunu sosyal sorumluluk olarak da yapıyoruz. Futboldan öte bir şey. Üniversiteye gidiyorlar. Biz bunu teşvik ediyoruz... Milliliğini vermek istiyoruz ki üniversiteye gitsin hayatı kurtulsun...Altyapıdaki kızı mesela alıyorum karşıma "bak kızım" diyorum "senin sorumluluğun var tüm kadınlara karşı sadece kendin değil. Güçlü bir kadın olduğunu göstereceksin. Kadınlara bir şey katman lazım."

"Futboldan öte" ifadesini kullanan Hakan, kadın futbolunun futbol dışılığını kadın için hayati bir şey olarak anlatıyor. Öyle ki futbol aracı sayesinde kadın formel eğitim alabilecek ve yaşayabilecek. O, "tüm kadınlar"a karşı sorumlu ve onun futbolu adeta kadınlığın ta kendisini kurtaracak. Federasyonda görüştügümm bir yetkili bana benzer bir bakış açısı sundu: "Kadın futbolunda önemli olan sportif başarı değil. Toplumsal. Öyle olmak zorunda." Yine başka bir antrenör, Ahmet, şöyle konuştu:

Biz bu işe proje olarak başladık. Yurtlardaki kız çocuklarını spor yapmaya teşvik için...arka mahallelerden gelen kızları topluma kazandırmak için. Sosyal belediyecilik kapsamında...

Futbolcu Nil'in anlatısı ise yukarıdaki araçsallaştırıcı ifadeleri doğruluyor ama kendisinin bu dinamiği ve futbolda neyin yaşamsal olduğunu farklı anlamlandırdığını gösteriyor:

Oğlanlara sporcu yetiştiriyorum diye bakıyor. 16-17 yaşında onun atacağı profesyonel imza hem kendisi hem hocası için önemli. Kendi hayatı kurtulur, hocasının reklamı olur...O artık onun sporcusu olur. Bu dünyada profesyonel imza hayat kurtarır. Ötesi yok.

Nil, yukarıda da söz ettiğim gibi, başka bir şey için değil, yeterince kazanmadığı için üniversite okuduğunu belirtti. Fakat, bunu amaç edinen araçsallaştırıcı yaklaşımın aksine, esas "kurtarıcı"nın üniversite eğitimi olduğu kanısında değil. Ona göre hayati olan, tam da araçsallaştıran algının tersine, futbolunun iş olarak, kendisinin "sporcu" olarak resmen tasdiklenmesi. Yukarıda Hakan “futbolun öte"sinde bir misyondan söz ediyor ama Nil'e göre "ötesi yok."

Yukarıdaki üç farklı otorite pozisyonundaki erkek figürlerin aynı çizgideki sözleri Türkiye kadın futbolu literatüründe eleştirilmiş bir bakış açısını yansıtıyor. Pınar Öztürk (2017) kadın futboluna ilişkin bu "projeci" yaklaşımı, yani bir sosyal proje olarak futbolu araçsallaştırma ve kadınları "kurtarmak" için bir hediye gibi lütfetme durumunu eleştirir. Bir "medenileştirme misyonu” örneği olarak okunabilecek bu üstten yaklaşım, aslında Türkiye'de kadın ve spor ilişkilenmesinin bir modernleşme adımı olarak kurgulanmış olmasını da hatırlatıyor (bkz. Pfister ve Hacısoftaoğlu 2016). Bu bağlamda kadın kapitalist ekonomiye, formel eğitim ve normatif aile kurumlarına entegre olmak için sporla ilişkilenir, bu misyonlar tamamlandığında da futbolu birakabilir.

Bireysel ilişkiler düzleminde bakıldığında bu kurtarma ya da yardım etme misyonu akrabalık/hısımlık terminolojisinin sık kullanılmasını, yani bir futbolcu katılımcının sözleriyle "herkesin baba, herkesin ağabey" olarak görülmesini beraberinde getiriyor. Hakan’ın sözlerindeki "kızım” hitabı bunu doğruluyor. İlişkilerin bu dille kurulması, yine kadın emeğinin "iş” olarak değerlenmediği başka durumlarda olduğu gibi (bkz. Leinaweaver 2008), kadının bir "meslek" icra ediyor olma tahayyülünün önünü bir kere daha kapatıyor. 
Kadın futbolu erkekler için bir kadına yardım mekanizması olmanın yanı sıra bir kariyer adımı. Konuştuğum bir başka antrenör Özlem'e göre, “erkekler bunu bir basamak olarak görürler.” Hakan'ın kendi ifadesine göre de:

Kimse istemez kadın futbolunu. Kimsenin hedefi değildir...Ama ben şimdi erkek takımında altyapıda olsam hedefim A takımına oyuncu yetiştirmek olacak, burada başka hedefler var. Kupa var...Ben bundan sonra artık dünyada her takımda çalışabilirim.

Kadın futbolundaki erkekler bir taraftan sahip oldukları varsayılan futbol alanındalar. Öte yandan bir oksimoron olarak algılanan "kadın futbolu" evrenine mensuplar. Burada olmaları dolaylı olarak kendilerinin de kadın futbolu ikincilleştirilmesinden mustarip olmasını getirebiliyor. Kadın futbolunu hem bir sıçrama tahtası olarak konumlandırmak, hem de rollerini "kadına yardım” olarak kurgulamak buradaki var oluşlarını adeta telafi ediyor.

\section{Futbolda "olmaması gereken yerde olan" kadın}

Kadın futbolu dünyada görünürlüğü artıyor. Hatta kadınlar arasındaki en popüler sporun futbol olduğu dahi yazılıyor (Andersson and Barker-Ruchti 2019). Kadın dünya kupası, her geçen turnuvada daha çok ses getiriyor. Öte yandan, çok değil, sadece birkaç on yıl önce kadınlara futbol oynamanın düpedüz yasadışı olduğu yerler var (Öztürk ve Koca 2015; da Costa 2014, Williams 2003). Gerekçelendirme çoğu zaman kadının futbol oynamasının "sağlıksız” (özellikle potansiyel anneliği açısından), "doğaya aykırı,” ya da estetik olarak itici olması. Yasanın durdurmadığı başka yerlerde de kadınlar ciddi engellerle karşılaşıyor, bazen bu değersizleştirme üzerinden oluyor, bazen de kadın oyunun basbayağı "kötü" olduğu öne sürülüyor (Hjelm 2011). Dolayısıyla futbolun kadına yakıştırılmaması, doğasına, eğilimlerine, toplumsal rollerine aykırı olduğu anlatıları yaygın ve alışılmış. Bu bölümde bu ötekileştirmenin fiziksel ve duyusal bir yerden nasıl tezahür ettiğini göstermek istiyorum. Kadın için ancak bir hobi ya da bir araç olarak kabul edilebilmesinden hareketle kadının futbolun sadece kavramsal alanı değil, fiziksel mekanları içindeki varlığı da bir yanlış yerde olma hali olarak karşımıza çıkıyor.

Giriş bölümünde de söz ettiğim gibi Mary Douglas (1966) kiri "olmaması gereken yerde olan" biçiminde tanımlar. Yani "kir" aslında bir karışmanın, katışmanın, bir ihlalin ya da sınır aşımının sonucunda karşımıza çıkandır. Örneğin, saç teli başımıza olduğunda kirliliği, pisliği göstermez ama yemek masasında olduğunda gösterir. İğrendirir. Çünkü yeri değişmiştir, olmaması gereken yerde, yanlış yerdedir. Düzeni tehdit eder. Bu kavramsal sınırlar kültürel olarak belirlenir, geçiş halinde olmak, arada-derede olmak ya da sınırı bütünüyle geçmiş olmak kirliliğe, bunun da ötesinde bir tehdide ve tehlikeye işaret eder. Birçok bağlamda bu açıdan "iğrenç" (abject) olan aslında yeri bedenin içi olan dolayısıyla da bedenden çıktığı anda "yanlış yerde" olan ve pislik göstergesi olan, sümük, dışkı, ter, tükürük, kusmuk, kan gibi bedensel atıklardır. Douglas (1966) özellikle regl kanının ve buradan hareketle de regl olan kadının tehlike ve tehdit unsuru olabileceğini, dolayısıyla da toplumlardaki hareketliliğinin, yapabilirliğinin, katılımının kısıtlanmış olmasını, bu kavramsallaştırma çerçevesinde ele alır. Kadının futbol “yer”lerine ait olmadığı algısını, bu yazının başında verdiğim 7 Mart maçına da bağlamak için, çoğunlukla Beşiktaş örnekleri ve takımın kendisine alan açmak için verdiği mücadeleler üzerinden anlatacağım.

Beşiktaş Jimnastik Kulübü'nün futbol altyapı tesisleri ve takımların iç sahası İstanbul'un Fulya semtinde. Ama kadın takımı için burada maç yapabilmek hep bir mücadele konusu olmuş. ${ }^{9}$ Bugün başka bir kulüpte ama eskiden Beşiktaş’ta oynayan Merve şöyle anlatıyor:

Beşiktaş’ta oynamaya başladığımda Fulya'da tadilat vardı. Biz orada tel örgülerin arasından sızıp girip içerde idman yapıyorduk. Ha erkek takımlarına yer buluyorlardı bu arada, bize yer yoktu. Sonra tadilat bitti, yine vermediler. Çilekli'de [Levent semtinde bir belediye halı sahası] oynadık iç saha maçlarını hep.

Bir başka futbolcu, Büke’ye göre:

Biz Fulya'da oynayamıyorduk. Çilekli'de o felaket zeminde oynuyorduk. Orada biz evimizdeki maçları oynuyorduk ama orası bizim evimiz değil. Deplasman gibi gidiyorduk...her gün olduğun, idman yaptığın, bildiğin, tanıdığın yerde maç yapmak çok farklıdır. Farklı bir güvendir. 
Buraya kadar bakıldığında futbolcuların altyapı tesislerinde yer edinmekte güçlük çekmesi genel bir ikincilleştirme hikayesinin bir parçası olarak okunabilir. Fakat bu değerlendirmelere ek olarak futbolcu Şermin, kadın futbolunu izlemeye başka altyapı takımlarından çok taraftar geldiğini ve bunun nedeninin de kadınların "götüne başına bakma isteğii” olarak yorumlandığını anlattı. Şermin’e göre Fulya'dan gönderilmelerinin ardında böyle bir gerekçelendirme vardı.

Bu gerekçelendirmeyi başkalarından duymadım, öte yandan "sahici” olup olmadığ 1 antropolojik olarak benim için ikinci planda. Bu kadının kendi yerinden edilme hikayesini bu şekilde okumuş olması, böyle anlamlandırması kendi içerisinde kıymetli bir veri. Bu anlatı kadının iç sahasında ya da "evinde" var olmasını cinselleştirme üzerinden bir sakınca ve itilme olarak deneyimlediğine işaret ediyor, önceki barınamama alıntılarına da bir katman ekliyor. Douglas'ın vurguladığı gibi, burada varoluş (yani "var" olma hali) kadınlığın cinselleştirilmesi üzerinden anlamlandırılıyor ve bu var olunan yerin yanlış ve sakıncalı bir yer olduğu hükmüyle sonuçlanıyor. Burada görüldüğü ve Nirmal Puwar'ın (2004) da söz ettiği gibi, futbolda kadınlar "mekan işgalcileri," ("space invaders") çünkü hem kavramsal hem de fiziksel olarak bazı sınırları tehdit ediyorlar, zorluyorlar hatta geçiyorlar (ayrica bkz. Black ve Fielding-Lloyd 2019).

Beşiktaş'ın erkek A takımı maçlarını 2013'te yenilenen, kırk bini aşkın kişilik Vodafone Park Stadyumu'nda oynuyor. Kadın takımının ise bu stadyumla olan ilişkisi son derece çetrefilli. Büke'ye göre "Vodafone'da pek yer[leri] yok." Örneğin, şampiyon oldukları 2019 sezonunun kupasını almak için kendilerine Vodafone Park'ta bir tören düzenleniyor. Bana anlatılana göre, takım törenin ya devrede ya da maçtan hemen önce olmasını istiyor. Bu şekilde tribünler dolu olabilecek, onlar da taraftarı selamlayabilecekler. Buna izin çıkmıyor. Stadyuma erkek takımının ısınma idmanından önce giriyorlar (ki girerken kendi yaka kartları olmadığı için 1şıkçı, teknisyen, vs. ekibinin yaka kartlarını kullanabiliyorlar); boş stadyumda kupa kaldırıyorlar. Bir keresinde ise takım erkek takımıyla birlikte ısınmaya çıkmak istiyor. Bu talepleri de reddediliyor. Şermin'e göre: "İstemediler. Bizim erkek takımıyla karışmamızı, konuşmamızı, temas etmemizi istemediler."

Başka bir takımda ve milli takımda oynayan Serpil kadın futbolunun nasıl algılandığına ilişkin konuşurken şöyle anlattı:

A takımından bizi uzaklaştırmaya çalışıyorlar. Ayrı tutmaya çalışıyorlar. Onlarla karşılaşalım istemiyorlar. Ne olur yani biz onları görsel, ne olacak ki? En fazla iyi bir şey olur. Motivasyon olur. Hayır görüşelim istemiyorlar.

Bu karıştırmama, katıştırmama, karşılaştırmama anlatıları Douglas'ın sınır-aşımı tehdidi kavramsallaştırmasını hatırlatıyor. Kadının futbola, futbolun erkekliğine girmesi, adeta işinden olmayan (olmadığı düşünülen) "iş"e karışması, kupasıyla, bacağıyla orada olması "istenmiyor." Bu istenmeme halini dile getiren futbolcular durumu anlamlandırmakta güçlük çekti. Çok fazla üzerinde durulmasa da kadınların erkek takımlarının konsantrasyonunu dağıtma ihtimalinden söz edildi - ki bu da kadının futbolu bir "iş" olarak icra edebileceğini yok sayan, heteronormatif bir cinselleştirme hamlesi.

Vodafone Park özelinde, kadınların içeri alınmaması, kulüp aktörleri tarafından çoğu zaman çimin kıymetine bağlanıyor. Çimin zarar görmesinin kulüp için ne kadar büyük bir kayıp olacağı vurgulanıyor. Kadın futbolcular bu anlatıları doğrularcasına stadyumda bulundukları zamanlarda mütemadiyen (krampon giyiyor olsalar bile) "çimlere basmayın" uyarılarına maruz kaldıklarını belirttiler. Sponsorluk tarafından bir katılımcı ise durumu bana şöyle ifade etti: "Burası mabet. Bu çimleri o adamlar öpüyor. Orada bir kadının olmasını tahayyül dahi edemiyorlar.” Dolayısıyla kadının Vodafone'dan engellenmesi, yine Douglas'ı hatırlatacak biçimde, kutsal olanın kirlenmemesi, tehlikenin kutsala müdahale etmemesi için alınmış bir önlem. Yani kadının verdiği düşünülen "zarar" maddi olmaktan çok sembolik ama kendini fiziksel bir dışlamayla gösterebiliyor. İşte bütün bu yüke sahip olduğu için kadın takımının Vodafone'da maç yapmış olması mühim.

Kadının futbol alanı üzerinde bir iddiası olmasının aykırılığı ve tehditkarlığı spor gazeteciliği penceresinden bakıldığında da karşımıza çıkıyor. Görüştüğüm bir spiker, Canan, bana bir kadın olarak futbol yorumcusu olmanın neredeyse mümkün olmadığını anlattı. Buna göre, erkek futbolu çok "değerli” bir yayın ve bir kadına "emanet edilmesi” söz konusu bile değil. Kendi deneyimindeki (on yıl bu işi yapmış bir profesyonel) bir erkek spikerin çoktan futbol anlatmaya başlamış olacağını, kendisinin ise kariyerine ilişkin bu ihtimalin bile değerlendirilmediğini söyledi. Futbolda kadın sesinin “tırmaladı̆̆g” algısını şöyle yorumladı: 
Bak, futbol erkeklerin hiçbir kadınla konuşmadıkları bir konu. Düşün adam bunu karısıyla bile paylaşmıyor. Özel bir alan bu. Erkeğe özel alan. Ve buraya bir kadın sesi girmesi, gerçekten bir işgal olarak algılanıyor. Spiker dediğin aslında bir hikaye yaratıyor. Evin içine giriyor. Yani mesela güzel bacaklı bir kadından spor haberi dinleyebiliyor adam ama doğrudan maçın içine girerse o zaman bambaşka anlamları oluyor, çok daha derin oluyor. İzleyici o ses, o spiker sayesinde o hikayenin bir parçası oluyor. Ve bu bir kadın sesi olduğu zaman, o deneyimi bir kadınla paylaşmak zorunda kalmış oluyor.

Kadın sesinin futbola süzülen bir "işgal” olarak kabul edildiğini dile getiren bu anlatı aslında kadının bedeninin (bu örnekte sesinin) futbolun içinde olmasının nasıl derin bir sınır aşımı olduğunu ifade ediyor. "Tırmalayan," "işgal eden" o sesi futbol maçının dışında tutmak dünyanın bilindiği gibi devam etmesi, düzenin ve güvenliğin tesis edilmesi için bir koşul, bir ihtiyaç oluyor. Öte yandan Canan'a göre, bir kadın spikerin (medyada temsil bulduğu nadir durumlarda) kadın futbolunu yorumlaması görece daha pürüzsüz çünkü bu yayın erkek spikerler ve kanal otoriteleri tarafindan aynı şekilde "değerli" bulunmuyor, hatta "iş" değil "angarya" olarak yorumlanıyor. Kadın futbolunun kendisinin bir "iş" olarak düşünülmemesine paralel olarak yayınının da işten sayılmadığı bu düzene rağmen, kadın futbolu yorumculuğu bir kadın spikere verildiğinde bu bir "lütfetme" anlayışıyla ve ek mesai bedeliyle olabiliyor.

Kadının futboldan ötelenmesinin, futbolun onun için "yanlış yer" olduğunun bir dişavurumu da homofobi. Cassandra Ogunniyi (2014) şöyle açıklıyor:

Futbol öncelikle bir "erkek oyunu” olarak anlaşıldığı için, futbola katılan kadınlar sapkın oluyorlar. Bu kadınlar hem medyanın, hem oyun alanlarının hem de finansal desteğin çeperine koyuluyorlar; çeperde muamele görüyorlar. "Doğallık" anlatıları onları erkeklik alanlarına el uzatmaktan alı koymak için kullanılıyor. Lezbiyen damgaları da onları cinsel olarak muğlak ve sapkın bir kategoriye sokarak daha da fazla dişlıyor. $(543)^{10}$

Burada da anlatıldığı gibi, özellikle dış görünüş açısından "kadınsı" normlara uyan kadınlar için futbol görece daha rahat var olunabilen bir alan (da Costa 2014, Fisher ve Dennehy 2015, Ben Porat 2020, Peeters, Elling ve Van Sterkenburg 2019). Türkiye'de yıllar boyunca futbolcu kadınlar antrenörlerinden saçlarını uzatmaları gerektiği tembih ve talepleriyle top oynadılar. Hatta öyle ki, "kısa saçlı" sıfatı kendi içinde bir ihlal, bir aşım göstergesi haline geldi (ayrıca bkz. Bora 2009). Bunun yanında bacak tüylerinin alınması ya da genel anlamda "bakımlı" olmak gibi koşullar söz konusu. Antrenör Hakan bana şunu anlattı:

Zannediyorlar ki futbol bir erkek oyunudur. O yüzden de erkek gibi olmaya çalışıyorlar. Aslında lezbiyen değiller. Özeniyorlar. Bazıları duygusal bir boşluğu kapatmaya çalışıyor, takım arkadaşlarından ilgi görünce de bu hoşuna gidiyor. Özellikle genç oyuncular saçlarını kesince ben çok sinirleniyorum. Yanlış yani bu. Burada kadın futbolundan konuşuyoruz. "Kadın” diyoruz. "Kadın da futbol oynayabilir" diyoruz. O zaman o kadınlığını öne çıkar. Kadın ol. Yoksa kadın futbolunu antipatik bir şey haline getiriyorsun.

$\mathrm{Bu}$ anlatının bir şekilde dillendiğiyle çok kere karşılaştım. Cinsiyet ikiliğinin altı çiziliyor, cinsiyet ifadesinin normlarına göndermeler yapılıyor, eşcinsellik hem ötekileştiriliyor hem de yok sayılıyor. Halbuki, yukarıdaki alıntının sahibi antrenör bana lezbiyen oyuncu oynatmaktan vazgeçse oynatacak kadın bulamayacağını da söyledi. Esas olarak, kadınların ne isterlerse yapabileceklerini ama bunu kulübe getirmemelerini ve "erkeksi" görünmemelerini istediğini belirtti (bu konuda bkz. Caudwell 1999, Harris 2005). Partnerinden ayrılmadı̆̆ takdirde oynadığı takımdaki yerini kaybedeceğine ilişkin tehditler, ailelerin lezbiyen kadınları hetero evlilikler yapmaya zorlaması, kadınların sadece şekil itibarıyla makul görünmek için erkek arkadaş gösterme hikayelerini sık sık dinledim. Dolayısıyla kadın futbolu içinde açık lezbiyenliğe de cinsiyet normlarını yeniden üretmeyen ifadelere de yer olmadığını söylemek mümkün. ${ }^{11}$

Araştırmamın katılımcıları arasındaki iki eski futbolcu da açık eşcinseller. Biri, Serra, Türkiye'de özellikle 2010'larda sayısı artan alternatif, kuir futbol takımlarından birinde hâlâ oynamakta (bu takımlarla ilgili ayrıntılı bilgi için bkz. Aktan 2018). Serra'nın anlatasına göre lezbiyenlerin futbolun içinde var olması ve görünür olması kendi içinde "özgürleştirici" bir şey çünkü bu alan hem kadınlara hem lezbiyenlere tarih içinde 
ve birçok yerde açık açık reddedilmiş, yasaklı bir alan. Diğer eski futbolcu Maud ise lezbiyen kadınların doğrudan futbol normlarını tehdit ettiğini çünkü hem futbola giren kadınlar olarak bir sınırı aştıklarını, hem de lezbiyen olarak cinsel ve cinsiyet sınırlarını aştıklarını anlatıyor. Dolayısıyla bu çifte aşım, hem toplumsal, hem de futbol özelinde sıkı sıkıya sarılınan normları tehdit ediyor, düzeni bozuyor. Kadın, ve bu örneklerde özel olarak lezbiyen kadın, futbolun tehlikeli ötekisi olarak karşımıza çıkıyor.

Bir futbolcu katılımcı bana destek ve sponsorluk eksikliğini anlatırken, biraz da tedirgin bir ifadeyle, "sanırım burayı kendi alanları olarak görüyorlar" dedi. "Acaba biz onları tehdit mi ediyoruz?" diye ekledi. Daha deneyimli ve yaşça daha büyük olan bir antrenör, Özlem, ise "Bizi birer tehdit olarak görüyorlar. Görsünler de zaten!" diye çıkıştı. Aslında bir tehdit olarak görülüyor olmayı değersizleştirmenin, önemsizleştirmenin tersi olarak kurguladı, en azından varlıklarının idrak edildiğinin bir göstergesi olarak yorumladı. Halbuki kadının varlığının bir "tehdit" olarak idrak edilmesi, tam da onun futbol alanındaki varlığının "yersiz," "yanlış," "olmaması gereken" bir şey olduğunun, işgalci, sınırları tehdit eden ve son kertede tehlikeli bir şey olduğunun ifadesi. Tehdit algısı, işinden olmayan işe karışma değerlendirmesinden besleniyor, hem kadını itmeye hem de normatif kadınlığı yeniden üretmeye hizmet ediyor.

\section{Sonuç yerine}

Bütün bunlar göz önünde bulundurulduğunda Beşiktaş'ın kadın takımının Vodafone Park'ta maç yapması anlamı yüklü bir gelişme. Bu maçın organize edilmesi için Beşiktaş kulübü, özellikle de altyapıdan sorumlu yöneticiler, kendi kulüpleriyle de dahil olmak üzere, uzun mücadeleler verdiler. Sonunda maç Vodafone sponsorluğunda yine Vodafone'un desteklediği Atletico de Madrid takımıyla bir dostluk maçı olarak ve bir kadınlar günü etkinliği olarak organize edildi. Yani kadınlar bu sahaya girdiler ama gündelik futbol hayatının işleyişi içinde değil, sıra dışı (sıranın dışına çıkan) bir etkinlik ve bir pazarlama kampanyasının ögeleri olarak girdiler.

Futbol içinde kadınların ötekileştirmesi bu yazıdaki referansların da gösterdiği gibi Türkiye'ye özgü bir şey değil; bunun kendisi önemli bir veri. Daha önce de söz ettiğim gibi, kadın futbolunun öne çıktığı birden çok yerde hâlâ eşit işe eşit ücret mücadelesi devam ediyor (Archer ve Prange 2019). Yaptığım futbolcu görüşmelerinde söz eşitliğe geldiğinde ben de bu örnekleri verdim. Aldığım cevaplar ise, neredeyse ağız birliği yapmış gibi, futbolcuların "biz henüz orada değiliz" değerlendirmeleri oldu. Bu cevabı ayrıntılandırmalarını dilediğimde aslında mücadelenin devam ettiği başka ülkelerdeki kadın futbolu ortamlarına öykündüklerini, Türkiye'de maddi (ücretlendirme, tesis, konaklama, fikstür, sağlık, vs.) ve manevi (değer verilme, destek görme, sporcu sayılma, vs.) koşullara ilişkin daha "temel” sorunlar tespit ettiklerini gördüm.

Yine burada anlatılan ikincilleştirme hikayelerinin erkek altyapı takımları için de geçerli olduğundan söz edilebilir. Burada da kadınların durumunu ayrı kılan, yukarıda da birbirine bağlayarak gösterdiğim, iki önemli etken var: Birincisi erkekler bu alanın sahipleri. Burası onların yeri, onlar buraya aitler ve birer tehdit unsuru değiller. Hem bu nedenle, hem de bu algıyı besleyecek şekilde onların futbol oynuyor olması (potansiyel de olsa) bir "iş" olarak görülüyor. Reşit olmayan erkek futbolcular bile profesyonel imzalar atabiliyor, yeri geldiğinde tüm ailelerine gelir sağlayabiliyorlar. Antrenörler erkek futbolcularına "sporcu yetiştirme" gözüyle, kadın futbolcularına ise "toplumsal sorumluluk projesi" olarak bakıyorlar.

Son olarak, burada anlatılanlar elbette kadın sporuna bakışın ve kadın sporu algısının bir tezahürü (bkz. Hargreaves 1994, Hargreaves 2000, Guttmann 1991, Messner 1992). Türkiye'de de kadın ve spor ilişkisinin ta kendisi buranın esas sahibini ve ötekiyi tanımlayacak biçimde kurulu (bkz. Pfister ve Hacısoftaoğlu 2016, Koca ve Hacısoftaoğlu 2011). Bu ötekileştirme durumu fiziksel aktivitenin bütününe ilişkin olabildiği gibi, erkeklikle özdeşleştirilen sporlarda, örneğin boks, daha belirgin (Emir, Karaçam ve Koca 2015). Futbolun ve kadın futbolunun bu yıldız haritasındaki önemi ise hem var olan bu örüntüleri yansıtmasından, hem de ülkede farklı ölçeklerde eylenme, izlenme, desteklenme, bilinme, görülme, takip edilme, değerlenme ve siyasileşme açılarından diğer spor branşlarına göre çok daha yoğun ve yaygın olmasından kaynaklanıyor.

$\mathrm{Bu}$ yazıda anlattıklarımın bir açıdan daha çözümlemeye değer olduğunu düşünüyorum. Geçtiğimiz birkaç sene içinde ülkede kadın futbolu üzerine atlet, antrenör, yönetici ve akademisyenleri bir araya getiren organizasyonlar oldu. Bu kapsamda özellikle Kadınlar için Spor ve Fiziksel Aktivite Derneği'nin (KASFAD) çalışmaları ve kadın futbolunun belli başlı aktörleriyle kuvvetli ilişkileri var (Öztürk ve Göktürk 2018). Bu çalışmaların medya görünürlükleri artmaya ve mesela "kadın futbol inisiyatifi," ya da "kadın futbol ağı" gibi sosyal medya hesapları ilgi görmeye başladı. TFF'de yaptığım görüşmeler sırasında ise doğrudan kadın sporcuların haklarına korumaya ilişkin bağımsız bir sivil toplum girişiminin kurulum aşamasında olduğunu öğrendim. 
Öte yandan ben araştırmam süresince görüştüğüm kadınlara maruz kaldıkları ayrımcılıkla ilgili harekete geçip geçemeyeceklerini, bu konuda herhangi bir örgütlenme olup olmadığını sorduğumda, her seferinde "hayır" cevabının aldım. İş koşullarının getirdiği prekar durumun kendilerini bağladığını, homofobi gibi konularla ise baş edecek donanım ya da desteğe sahip olmadıklarını anlattılar. Bununla beraber bazı daha genç futbolcu katılımcıların (17-22 yaş arası) bir miktar daha umutlu ve değişime ön ayak olmak konusunda şevkli olduğunu gördüm. Bu konuyu ayrıntılandırdıklarında söz ettikleri sponsorlukların artması, kadın teknik sorumlu sayısının artması, uluslararası düzlemde kadın futbolunun ve kadın futbolcu figürlerin görünürlüğünün yükselmesi, Türkiyeli kadın futbolcuların yurt dışı takımlara transfer olması ya da yurt dışında futbol bursuyla üniversite okuyabilmeleri gibi deneyim ve gelişmeler oldu. Fakat onlar da yine tek uğraş ya da kariyer olarak futbol oynamanın kadınlar için gerçekçi bir hedef olduğu kanısında değildiler.

Dolayısıyla, son dönemde farklı kadın futbolu aktörlerini bir araya getiren sivil toplum mücadeleleri benim araştırmamda doğrudan öne çıkmadı. Öte yandan, özellikle genç bazı futbolcuların kendilerini küresel olarak zenginleşen kadın futbolu evreninin bir üyesi olarak görmeleri ve bu bakış açısı sayesinde futbol içindeki varlıkları konusunda görece daha güvende hissetmeleri dolaylı olarak ülkedeki kadın futboluna ilişkin başlatılmış olan mücadelenin bir yankısı, aynı evrenin bir bileşeni olarak düşünülebilir.

Yukarıda anlatılanlara ek olarak Vodafone Park'taki maç Türkiye'de futbol izlemenin kurallarının da dışına çıkmaya izin verecek biçimde yapılandırıldı. Sporda Şiddet ve Düzensizliği Önleme Kanunu'nun gerekliliği olan Passolig ve e-bilet sistemi kullanılmadı. Maç için kağıt bilet basıldı ve biletler taraftara bedelsiz olarak verildi. $\mathrm{Bu}$ da aslında beraberinde endüstriyel futbolun ittiği, ötelediği taraftar gruplarının adım atamadıkları stadyuma gelebilmelerini, yine itilen, ötelenen birçok taraftarlık pratiğinin (içkili maça gelmek, meşale yakmak, küfürlü tezahürat gibi) icra edilebilmesini sağladı. Benim için bu maç tam da "olmaması yerde olanların" bir araya gelmesini deneyimlediğim bir etkinlik oldu. Kırk beşinci dakikada, olmaması gereken yerde olan 15-16 yaşlarında bir genç oğlan midesinde kalması gereken muhteviyatı, olmaması gereken yere, benim ceketimin arkasına doğru boşalttı. Olmaması gereken yerde olan tehditkar kadınlar, olmaması gereken yerde olan tehditkar taraftar bu "iğrenç" kusmukla buluştu. Futbolun içinde olmaması gerekenler hep bir ağızdan dışa vuruldu. Hoparlörlerden "ben varım” çınladı. Var olanlar orada olmaması gerektiği düşünülenlerdi. 
${ }^{1} \mathrm{Bu}$ takımda irtibat kurduğum futbolcu İstanbul'a maç için geldiklerinde kendisiyle görüşebileceğimi belirtti. Takım geldiğinde tek görüşme imkanım bu grup görüşmesi oldu.

${ }^{2} \mathrm{Az}$ sayıda görüşmeyi telefonda yapmış olmam bu katılımcıların yurt ya da şehir dışında olmalarından ve onları ziyaret edemediğimdendir.

${ }^{3}$ Her aktör kategorisinden kaç kişiyle konuştuğum saha çalışmasındaki erişebilme kısıtlarımla belirlendi. Burada yer verdiğim alıntılar beş ayrı futbol takımı, federasyon, medya ve sponsor temsilcilerine ve iki eski futbolcuya ait. Araştırmanın çeşitli aşamalarında katılımcılara erişmemi sağlayan Cem Tınaz, Emir Güney, Deniz Nihan Aktan, Elzem Seren Dinç, İlknur Hacısoftaoğlu, Sarp Samuray, Hazal Bayazıt ve Burkal Efe'ye teşekkür ederim. Bu araştırmanın bir kısmında Kerem Tokel bana asistanlık yaptı. Araştırmaya katkısı ve birlikte gittiğimiz maç sonrası aldığı notlar, gündeme getirdiği soru(n)lar için kendisine teşekkür ederim. Bu araştırmanın ilham kaynağı Georgetown University Qatar'daki “Ortadoğu'da Futbol Çalışma Grubu” katılımcılarına ayrıca teşekkür ederim.

${ }^{4}$ 2003-2006 yılları arasında verilen ara konusunda hem saha bulgularım hem de bu konuyla ilgili kaynaklar farklı gerekçelendirmelere işaret ediyor (bkz. Çolak, Barboros ve Yenidünya 2019, Orta 2014, Öztürk 2017) Ara ve ardındaki hikayeler, bu makale kapsamında olmayan ayrı bir araştırma konusudur.

${ }^{5}$ Lisanslı futbolcu sayılarına ve cinsiyet dağılımına ilişkin, TFF'deki irtibatlarımın da doğruladığı üzere, resmi veri yayımlanmıyor. Toplam futbolcu sayısının 600.000 üzerinde olarak açıklandığı bir röportaj için bkz. Dixon 2020.

${ }^{6}$ Türkiye ve Kürt azınlık ilişkisinin çeşitli boyutları sporda da kendini gösteriyor. Genel bir okuma için bkz. Yeğen 2007; Amed Sportif Faaliyetler kulübüyle ilgili bkz. Irak 2018; Amed'in isim değişikliğiyle ilgili bkz. Birgün 2017.

${ }^{7}$ Profesyonel statüye sahip olmanın idealize edilmemesi gerekir. Bu konuyla ilgili Danimarka ve İsveç örnekleri için bkz. Kjær ve Agergaard 2013; ayrıca Avrupa'da kadın futbolu ve profesyonelleşme üzerine bkz. Williams 2013.

${ }^{8}$ Veri ve kimliğin eșleștirilememesi kuralı çerçevesinde tüm katılımcı isimleri mahlastır.

${ }^{9}$ Takımın 2019-2020 sezonunda tekrar Fulya'ya dönmüş olmasını 2019 şampiyonluğuyla kendisini “kanıtlamış" olmasına bağlayan katılımcilar oldu.

${ }^{10}$ Çeviri yazara aittir.

${ }^{11}$ Kısa saçlı olmak ve bir dilsel gösterge olarak "kısa saçl1," kadın futbolunda homofobi bağlamında önemli bir konu. Bu bağlam ve konuyu başka bir makalede doğrudan ele alıyorum.

\section{Kaynakça}

Aktan, Deniz Nihan. 2018. "Sexuality and Politics on the Football Field.” Yayımlanmamış Yüksek Lisans tezi. Boğaziçi Üniversitesi, İstanbul.

Allison, Rachel. 2018. Kicking Center: Gender and the Selling of Women's Professional Soccer. New Brunswick: Rutgers University Press.

Andersson, Rebecca ve Natalie Barker-Ruchti. 2019. "Career Paths of Swedish Top-level Women Soccer Players." Soccer \& Society 20(6): 857-871.

Archer, Alfred ve Martine Prange. 2019. “"Equal play, Equal pay’: Moral Grounds for Equal Pay in Football.” Journal of the Philosophy of Sport, 46(3): 416-436.

Arpinar-Avsar, Pinar, Serkan Girgin ve Nefise Bulgu. 2014. "Lady or Woman? The Debate on Lexical Choice for Describing Females in Sport in the Turkish language." International Review for the Sociology of Sport 51(2): 178-200.

Ataşehir ekspres. 2016. "Kırmızı Beyazlıların Parolası: Şampiyonluk.” 20 Ekim. URL: http://edergi.atasehir.bel.tr/102016/mobile/index.html\#p=22

Ben Porat, Amir. 2020. “Cosi (non) Fan Tutte: Women’s Football ‘Made in Israel.” Soccer \& Society 21(1): 39-49.

Birgün. 2017. "Kayyum Amedspor’un İsminin Değiştirilmesini İstemiş." 19 Şubat. URL: https://www.birgun.net/haber/kayyum-amedspor-un-isminin-degistirilmesini-istemis-147450

Black, Jack ve Beth Fielding-Lloyd. 2019. "Re-establishing the 'Outsiders': English Press Coverage of the 2015 FIFA Women's World Cup.” International Review for the Sociology of Sport 54(3): 282-301.

Bora, Aksu 2015. Kadınların Sınıfi: Ücretli Ev Emeği ve Kadın Öznelliğinin İnşası. İstanbul: İletişim.

Bora, Tanıl. 2009. "Futbolun Kadınla İmtihanı.” Radikal, 30 Haziran. URL: http://www.radikal.com.tr/yazarlar/tanilbora/futbolun-kadinla-imtihani-942886/

Caudwell, Jayne. 1999. "Women's Football in the United Kingdom: Theorizing Gender and Unpacking the Butch Lesbian Image." Journal of Sport and Social Issues 23(4): 390-402. 
Clark, Cassandra. 2011. "Leading or Losing? Women Challenging Male Hegemony in South African Football and the FIFA World Cup." Soccer \& Society 12(6): 834-849.

Coche, Roxane. 2016. "Promoting Women's Soccer through Social Media: How the US Federation Used Twitter for the 2011 World Cup," Soccer \& Society 17(1): 90-108.

Connell, R.W. 1987. Gender and Power. Stanford: Stanford University Press.

Cox, Barbara ve Richard Pringle. 2011. "Gaining a Foothold in Football: A Genealogical Analysis of the Emergence of the Female Footballer in New Zealand.” International Review for the Sociology of Sport 47(2): 217-234.

Cumhuriyet. 1968. "Hanım Futbolcular Eşlerinden Veya Babalarından İzin Alacaklar." 23 Mart. URL: https://www.cumhuriyetarsivi.com/katalog/192/sayfa/1968/3/23/8.xhtml

Çolak, Alp, İlkay Barboros ve Merve Yenidünya. 2019. “Türkiye'de Kadın Futbolunun Var Olma Mücadelesi.” Maçkolik, 8 Haziran. URL: https://www.mackolik.com/futbol/haber/oezel-dosya-1-boeluem-tuerkiyede-kadinfutbolunun-var-olma-muecadelesi/195rbco5cs3u81pgwky7hqnb32

da Costa, Leda Maria. 2014. "Beauty, Effort and Talent: A Brief History of Brazilian Women's Soccer in Press Discourse.” Soccer \& Society 15(1): 81-92.

Dixon, Ed. 2020. “'It's Our Number ONe Sport, It's in Our DNA:' Can Turkey Climb Back to Soccer's Summit?” SportsPro, 21 Şubat. URL: https://www.sportspromedia.com/interviews/turkish-fa-tff-servet-yardimciinterview-uefa-super-lig-euro-2020

Douglas, Mary. 1966. Purity and Danger. New York, NY: Routlegde.

Emir, Esra, Mustafa Şahin Karaçam ve Canan Koca. 2015. “Kadın Boksörler: Boks Ringinde ve Ringin Dışında Sürekli Eldiven Giymek.” Spor Bilimleri Dergisi 26(4): 136-153.

Erdoğdu, Seyhan ve Gülay Toksöz. 2013. "The Visible Face of Women’s Invisible Labor: Domestic Workers in Turkey." ILO: Conditions of Work and Employment Series 42. Cenevre: ILO.

Federici, Silvia. 1975. Wages Against Housework. Bristol: The Power of Women Collective (için) Falling Wall Press.

Fisher, Caitlin ve Jane Dennehy. 2015. “Body Projects: Making, Remaking, and Inhabiting the Woman's Futebol Body in Brazil." Sport in Society 18(8): 995-1008.

Fozooni, Babak. 2008. "Iranian Women and Football.” Cultural Studies 22 (1): 114-133.

Glazer, Nona Y. 1984. "Servants to Capital: Unpaid Domestic Labor and Paid Work." Review of Radical Political Economics 16(1): 61-87.

Göktürk, Erdem. 2020. “Kadın Futboluna Dair 7: O Zaman Ne Yapmalı?” Gazete Duvar, 24 Haziran. URL: https://www.gazeteduvar.com.tr/spor/2020/06/24/kadin-futboluna-dair-7-o-zaman-ne-yapmali/

Guardian. 2019. "US Women's Team Sues US Soccer Over 'Institutionalized Gender Discrimination."” 8 Mart. URL: https://www.theguardian.com/football/2019/mar/08/usa-womens-team-sues-us-soccer-pay-equality

Guttmann, Allan. 1991. Women's Sports: A History. New York: Columbia University Press.

Hargreaves, Jennifer. 1994. Sporting Females: Critical Issues in the History and Sociology of Women's Sport. Londra: Taylor and Francis.

Hargreaves, Jennifer. 2000. Heroines of Sport: The Politics of Difference and Identity. Oxon: Routledge.

Harris, John. 2005. “The Image Problem in Women’s Football.” Journal of Sport \& Social Issues 29(2): 184-197.

Harkness, Geoff. 2012. "Spring forward: female Muslim soccer players in Iraqi Kurdistan.” Soccer \& Society 13(5-6): $720-738$.

Hochschild, Arlie Russel. 1983. The Managed Heart: Commercialization of Human Feeling. Berkeley: University of California Press. 
Hjelm, Jonny. 2011. "The Bad Female Football Player: Women's Football in Sweden.” Soccer \& Society 12(2): 143158 .

Irak, Dağhan. 2018. “Kurdish Identity and Sports in Turkey.” Society Register 2(1): 59-76.

Karaçam, Mustafa Şahin ve Canan Koca. 2019. “Men’s Resistance to Gender Equality in Sports Governance.” Agnes Elling, Jorid Hovden ve Annelies Knoppers (der.), Gender Diversity in European Sport Governance içinde (2535), Oxon: Routledge.

Kjær, Jørgen Bagger ve Sine Agergaard. 2013. “Understanding Women’s Professional Soccer: The Case of Denmark and Sweden." Soccer \& Society, 14(6): 816-833.

Koca, Canan ve Hacısoftaoğlu, İlknur. 2011. "Struggling for Empowerment: Sport Participation of Women and Girls in Turkey.” Tansin Benn, Gertrud Pfister ve Haifaa Jawad (der.), Muslim Women and Sport içinde (154-166), Oxon: Routledge.

Kotiswaran, Prabha. 2011. Dangerous Sex, Invisible Labor: Sex Work and the Law in India. Princeton: Princeton University Press.

Leinaweaver, Jessaca. 2008. The Circulation of Children: Kinship, Adoption, and Morality in Andean Peru. Durham, NC: Duke University Press.

Magee, Jonathan, Jayne Caudwell, Katie Liston ve Sheila Scraton.2007. Women, Football and Europe: Histories, Equity and Experience. Berkshire: Meyer \& Meyer Sport.

Meân, Lindsey. 2001. "Identity and Discursive Practice: Doing Gender on the Football Pitch." Discourse \& Society 12(6):789-815.

Messner, Michael A. 1992. Power at Play: Sports and the Problem of Masculinity. Boston: Beacon Press.

Ogunniyi, Cassandra. 2014. "Perceptions of the African Women's Championships: Female Footballers as Anomalies." Sport in Society 17(4), 543.

Orta, Lale. 2014. "Women and Football in Turkey." International Journal of Humanities and Social Sciences 4(7-1): $85-93$.

Ortner, Sherry B. 1974. "Is Female to Male as Nature is to Culture?” Michelle Zimbalist Rosaldo ve Louise Lamphere (der.), Woman, Culture, and Society içinde (68-87). Stanford: Stanford University Press.

Özgen, İlhan. 2014. “Bir Dinarsu Vard1, N’oldu?” Topraksaha. URL: http://topraksaha.net/03/2014/bir-dinarsu-vardinoldu/

Öztürk, Pınar. 2017. “Kadın Futbolcuların Futbol Alanındaki Deneyimleri.” Yayımlanmamış Doktora tezi. Hacettepe Üniversitesi, Ankara.

Öztürk, Pınar ve Canan. Koca. 2015. “Futbolun ‘Ötekisi’ Kadınlar, Fotoğrafın ‘Ötekisi’ Fotoromanı Yazıyor.” Moment Dergi 2(2): 157-183.

Öztürk, Pınar ve Canan Koca. 2018. "Futbolda Kadınlar: Bir Sosyal Alan Olarak Kadın Futbol Takımının Analizi." Türkiye Klinikleri 10(3): 150-163.

Öztürk, Pınar ve Erdem Göktürk. 2018. Kadın Futbol Çalıştayı Raporu. URL: https://www.kasfad.org/?p=2662

Peeters, Rens, Agnes Elling ve Jacco Van Sterkenburg. 2019. "WEURO 2017 as Catalyst? The Narratives of Two Female Pioneers in the Dutch Women's Football Media Complex." Soccer \& Society 20(7-8): 1095-1107.

Pfister, Gertrud. 2015a. "Assessing the Sociology of Sport: On Women and Football." International Review for the Sociology of Sport 50(4-5): 563-569.

Pfister, Gertrud. 2015b. "Sportswomen in the German popular press: A Study Carried Out in the Context of the 2011 Women's Football World Cup." Soccer \& Society 16(5-6): 639-656. 
Pfister, Gertrud ve Ilknur Hacısoftaoğlu. 2016. "Women’s Sport as a Symbol of Modernity: A Case Study in Turkey." 33(13): 1470-1482.

Puwar, Nirmal. 2004. Space Invaders: Race, Gender and Bodies Out of Place. New York, NY: Berg.

Ravel, Barbara ve Marc Gareau. 2016. “'French Football Needs More Women like Adriana”? Examining the Media Coverage of France's Women's National Football Team for the 2011 World Cup and the 2012 Olympic Games." International Review for the Sociology of Sport 51 (7): 833-847.

Scraton, Sheila, Kari Fasting, Gertrud Pfister ve Ana Bunuel. 1999. “It’s Still a Man's Game?: The Experiences of Toplevel European Footballers.” International Review for the Sociology of Sport 34(2): 99-111.

Stewart, Kenda R. “A hobby or Hobbling? Playing Palestinian Women’s Soccer in Israel.” Soccer \& Society, 13(5-6): 739-763.

Stirling, Louise ve John B. Schulz. 2011. "Women's Football: Still in the Hands of Men." International Sport Management Journal 7(2): 53-78.

Talimciler, Ahmet. 2020. "Futbolu Yönetenlerin Görmezden Geldiği Kadınlar Futbolu." T24, 13 Haziran. URL: https://t24.com.tr/yazarlar/ahmet-talimciler/futbolu-yonetenlerin-gormezden-geldigi-kadinlar-futbolu,26998

Themen, Kate. 2016. "Female Football Players in England: Examining the Emergence of Third-space Narratives." Soccer \& Society 17(4): 433-449.

Toklucu, Murat. 2016. "Futbol Kadını Bozar Mı?” 5 Harfliler. 4 Nisan. URL: http://www.5harfliler.com/futbol-kadinibozar-mi/

Williams, Jean. 2003. A Game for Rough Girls?: A History of Women's Football in Britain. Londra: Routledge.

Williams, Jean. 2013. Globalising Women's Football: Europe, Migration and Professionalization. Bern: Peter Lang.

Yeğen, Mesut. 2006. “Turkish Nationalism and the Kurdish Question.” Ethnic and Racial Studies 30(1): 119-151.

Zimmerman, Jess. 2015. “Where's My Cut?”: On Unpaid Emotional Labor.” The Toast, 13 Temmuz. URL: https://thetoast.net/2015/07/13/emotional-labor/ 